\title{
ANTHROPOGENIC INFLUENCES IN A LAGOONAL ENVIRONMENT: A MULTIPROXY APPROACH AT THE VALO GRANDE MOUTH, CANANÉIA-IGUAPE SYSTEM (SE BRAZIL)
}

\author{
Michel Michaelovitch de Mahiques ${ }^{l}$; Leticia Burone ${ }^{I}$; Rubens Cesar Lopes Figueira ${ }^{I}$; Ana Amélia de Oliveira \\ Lavenére-Wanderley ${ }^{2}$; Benjamim Capellari ${ }^{3}$; Carlos Eduardo Rogacheski ${ }^{2}$; Cassia Pianca Barroso ${ }^{2}$; Leonardo \\ Augusto Samaritano dos Santos $^{2}$; Luisa Mariutti Cordero ${ }^{2}$ and Mariana Coppede Cussioli ${ }^{2}$
}

${ }^{1}$ Instituto Oceanográfico da Universidade de São Paulo (Praça do Oceanográfico, 191, 05508-120 São Paulo, SP, Brasil)

${ }^{2}$ Instituto Oceanográfico da Universidade de São Paulo Programa de Pós-Graduação em Oceanografia Química e Geológica (Praça do Oceanográfico, 191, 05508-120 São Paulo, SP, Brasil)

${ }^{3}$ Instituto Oceanográfico da Universidade de São Paulo

Programa de Pós-Graduação em Oceanografia Física (Praça do Oceanográfico, 191, 05508-120 São Paulo, SP, Brasil)

*Corresponding Author: mahiques@usp.br

\section{A B S T R A C T}

The Cananéia-Iguape system, SE Brazil, consists of a complex of lagoonal channels, located in a United Nations Educational, Scientific and Cultural Organization (UNESCO) Biosphere Reserve. Nevertheless, important environmental changes have occurred in approximately the last 150 yrs due to the opening of an artificial channel, the Valo Grande, connecting the Ribeira de Iguape River to the lagoonal system. Our objective is to assess the historical record of the uppermost layers of the sedimentary column of the lagoonal system in order to determine the history of environmental changes caused by the opening of the artificial channel. In this sense, an integrated geochemicalfaunal approach is used. The environmental changes led significant modifications in salinity, in changes of the depositional patterns of sediments and foraminiferal assemblages (including periods of defaunation), and, more drastically, in the input of heavy metals to the coastal environment. The concentrations $\mathrm{Pb}$ in the core analyzed here were up to two times higher than the values measured in contaminated sediments from the Santos estuary, the most industrialized coastal zone in Brazil.

\section{RESUMO}

O sistema Cananéia-Iguape (Sudeste do Brasil), consiste em um complexo de canais lagunares localizados no interior de uma Reserva da Biosfera (assim definida pela UNESCO). Não obstante, variações ambientais importantes ocorreram nos últimos 150 anos, devido à abertura de um canal artificial, o Valo Grande, conectando o Rio Ribeira de Iguape ao sistema lagunar. O objetivo deste trabalho foi determinar a história das variações ambientais no sistema lagunar, causadas pela abertura do canal artificial, através da análise das camadas superiores da coluna sedimentar de um testemunho coletado no sistema. Neste sentido, uma abordagem integrada, envolvendo variações geoquímicas e faunísticas foi utilizada. As variações ambientais ocorridas apontam para mudanças drásticas na salinidade, nos padrões de sedimentação, nas associações de foraminíferos (incluindo períodos azóicos) e, mais drasticamente, no aporte de metais para o sistema costeiro. As concentrações de $\mathrm{Pb}$ no testemunho coletado indicam valores duas vezes maiores do que os medidos em sedimentos contaminados do estuário de Santos, situado na zona costeira mais industrializada do Brasil.

Descriptors: Anthropogenic influence, Lagoon, Sedimentation, SE Brazil.

Descritores: Influência antrópica, Laguna, Sedimentação, SE Brasil. 


\section{INTRODUCTION}

Due to their geomorphological and physicochemical properties, lagoons and estuaries are potential deposit areas for anthropogenic sediments, and the number of studies dealing with these subjects is increasing rapidly (JONES; TURKI, 1997; BIRCH; TAYLOR, 1999; CEARRETA et al., 2000, 2002; CUNDY et al., 2003; ELBERLING et al., 2003; PASTERNACK; BROWN, 2006; DONDERS et al., 2008; LEORRI et al., 2008). An important approach to the subject is related to the sedimentary record of this anthropogenic influence, which incorporates high resolution geochronology with proxies of different types so as to provide a reliable documentation of the contamination history of a given area (ALVE, 1991, 1995; PLATER et al., 1998; PLATER; APPEBY, 2004; LI et al., 2000; CHAN et al., 2001; CEARRETA et al., 2002; RUIZ-FERNÁNDEZ et al., 2007, among others).

Fox et al. (1999) studied metal levels (As, $\mathrm{Cr}, \mathrm{Cu}, \mathrm{Pb}, \mathrm{Hg}$ and $\mathrm{Zn})$, radionuclides $\left({ }^{137} \mathrm{Cs},{ }^{238} \mathrm{Pu}\right.$, ${ }^{239+240} \mathrm{Pu}$ and $\left.{ }^{241} \mathrm{Am}\right)$ and DDT in the Mersey Estuary (UK). In this study, a history of contamination of the area, from the pre-industrial period until the present day, was established. An increase in the contamination by heavy metals, which began in the 1930s, and by DDT, starting in the 1960s, was identified.

Dassenakis et al. (1995) studied the sediments of the Acheloos Estuary (Greece) where diverse human activities, such as dams, agriculture and navigation, influenced the system. These human actions, in combination with hydrological patterns and both mineralogical and morphological factors, affected the chemical behavior and heavy metal distribution patterns of this estuary's sediment. One important aspect of the estuary is that although it is not highly polluted, the enrichment of some metals in the coretops indicates the beginning of the anthropogenic influence on the system.

Other outstanding papers on the subject included those carried out by Cearreta et al. (2000, 2002) who identified the impact of the anthropogenic activities in the metal geochemistry and microfauna of the Bilbao Estuary (Northern Spain). Over a 150-year period, this estuary received effluents from mining and industrial and domestic waste, and it became the most polluted estuary in North of Spain. The integrated analysis of geochronology, heavy metals and microfauna permitted to recognize the degradation of the area during the time period considered.

Sedimentological records of mining activities in coastal areas and adjacent continental shelves have been reported in several previous papers. Hornberger et al. (1999) identified enrichment factors of about 20 in $\mathrm{Hg}$ concentrations in sediments of San Francisco Bay (USA), which were related to $\mathrm{Au}$ mining activities in the XIXth century. Corredeira et al. (2008) also identified enrichment of $\mathrm{Cu}, \mathrm{Zn}$ and $\mathrm{Pb}$ in the SW Iberian sediments associated with mining activities along the Iberian Pyrite Belt.

The Cananéia-Iguape system, SE Brazil (Fig. 1), consists of a complex of lagoonal channels, located in a United Nations Educational, Scientific and Cultural Organization (UNESCO) Biosphere Reserve. Nevertheless, important environmental changes have occurred in approximately the last 150 yrs due to the opening of an artificial channel, the Valo Grande, connecting the Ribeira de Iguape River to the lagoonal system. Also, due to $\mathrm{Ag}, \mathrm{Zn}$ and $\mathrm{Pb}$ mining activities that took place in the upstream region of the Ribeira de Iguape River, the system acted as a depository of contaminated sediments.

Our objective is to assess the historical record of the uppermost layers of the sedimentary column of the lagoonal system in order to determine the history of environmental changes caused by the opening of the artificial channel. In this sense, an integrated geochemical- faunal approach is used.

\section{Study Area}

\section{The Ribeira de Iguape River and the Valo Grande Channel (Fig. 1)}

The Ribeira River forms the largest drainage basin of the S-SE Brazilian coast (from $22^{\circ} \mathrm{S}$ to $30^{\circ} \mathrm{S}$ ), with an area of about $25,000 \mathrm{~km}^{2}$. The outflow of the river in its lower course varies from about 300 to more than $1,200 \mathrm{~m}^{3} / \mathrm{s}$, with the variation in flow influenced strongly by the subtropical humid climate.

Mining activities in the upper course of the river have been ongoing since the XVIIth century, originally as manual mining of $\mathrm{Au}$ and $\mathrm{Ag}$ and, from 1945, with the establishment of an industry of $\mathrm{Pb}$ mining (Plumbum S/A), which ceased its activities in 1995 due to the exhaustion of reserves, technological difficulties and economic factors.

The opening of a 4-km long artificial channel from the Ribeira River to the Cananéia-Iguape lagoonal system began in 1827 but was only finished in 1852 (GEOBRÁS, 1966). The aim of this channel was to shorten, and consequently to reduce the costs of, the transportation of agricultural goods (especially rice, the main economic product of the region) from the country lands to the main export harbor of the region (Porto Grande), located in Iguape city. After the opening of the channel, initially named Valo do Rocio and now named Valo Grande, about $60 \%$ of the main flow of the river flow was transferred to the lagoonal system, leading to a drastic decrease in salinity. Zero salinity values are presently observed in Cananéia City, located $60 \mathrm{~km}$ south of the channel mouth. Also, the coastal plain, where the channel was excavated, 
suffered a drastic erosional process, followed by a dramatic increase in the deposition of the adjacent lagoonal areas due to the siltation of the Mar Pequeno and Iguape harbor areas. Other critical problems, such as the reduction of cultivated and inhabitable areas, were also observed.

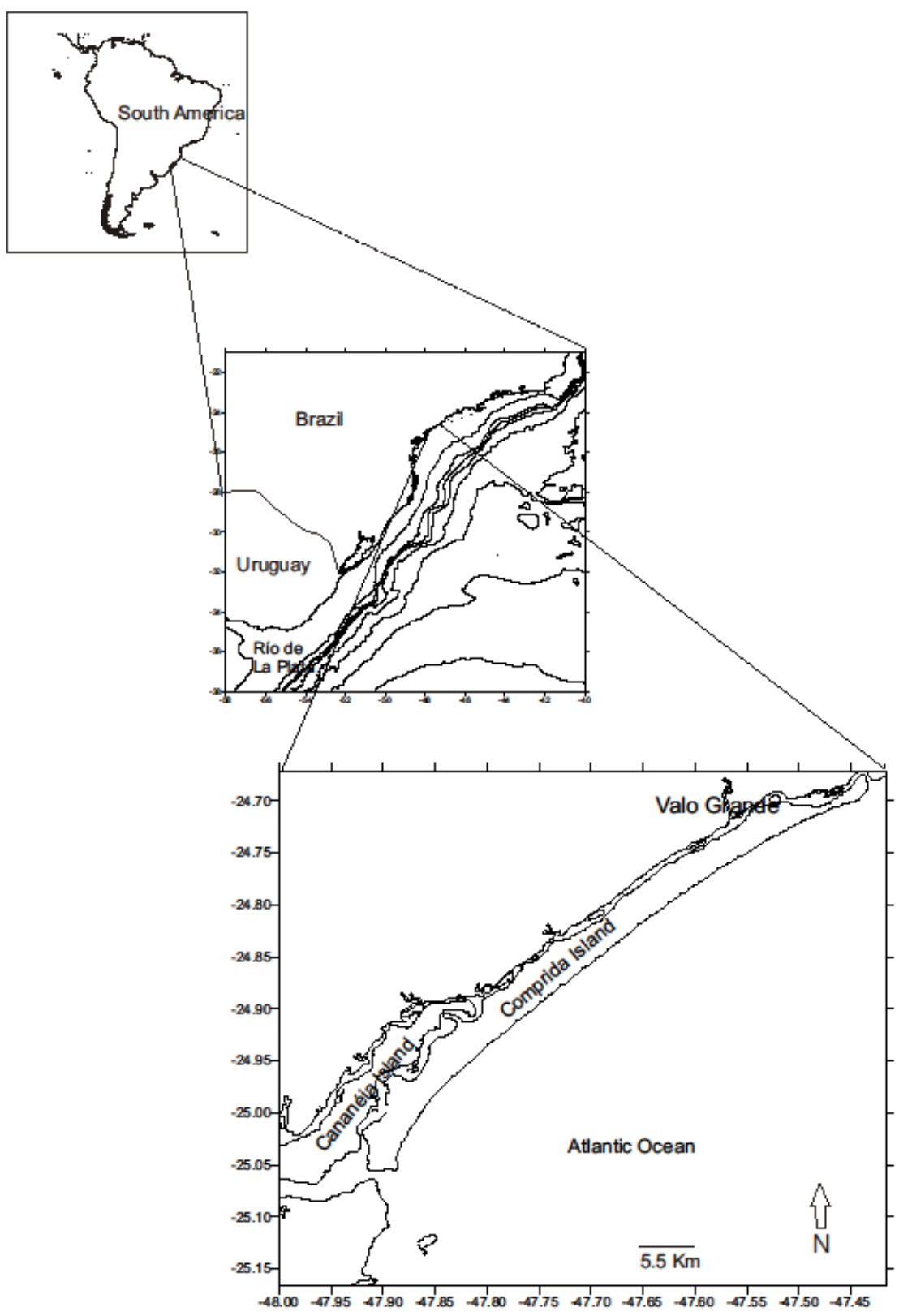

Fig. 1. Location of the study area. 
The original dimensions of the channel (4.4 meters wide and 2 meters deep) rapidly increased, and the channel currently presents a width of about 250 meters and depths of up to 7 meters. The name Valo Grande ("Big Scour") is a reference to the dimensions that the channel acquired just a few decades after it was opened.

The Valo Grande channel was closed in 1978 by a dam made of stones and sand, which was destroyed in 1983 after huge floodings of the Ribeira River that affected the areas located upstream and led to financial losses to the agriculture of the area.

\section{The Cananéia-Iguape Coastal Plain and the Estuarine-lagoonal System}

The geological and geomorphological characteristics of the Cananéia-Iguape system have been analyzed for at least six decades in several studies since the original papers by Besnard (1950), who proposed four stages of evolution based on geomorphological evidence. According to the author, the process occurred during the late Tertiary and the early Quaternary periods and was associated with a slow sea level regression forming the coastal plain. After this first work, the sedimentary evolution of this complex of estuarine and lagoonal channels and the associated coastal plain was analyzed extensively by several papers, such as Petri and Suguio (1971, 1973) and Suguio and Martin (1978). In addition, Martin and Suguio (1979) proposed a five-stage model of evolution to explain the origin of the Cananéia Iguape system. Essentially, the present lagoonal channels represent the drowning of the paleo-river channels developed after the transgressive phase of Isotope Stage 5e, locally named the Cananéia Transgression (120,000 years B.P).

According to the classification of Köppen, the climate of this system shows characteristics of a humid tropical climate, varying in decadal scale from humid tropical without a dry season to humid tropical with a cool summer. The rainfall shows average values of about $2200 \mathrm{~mm} . \mathrm{yr}^{-1}$, with a marked rainy season between November and February (the austral summer). Annual average temperatures vary from 16 to $19^{\circ} \mathrm{C}$, but temperatures as low as $0^{\circ} \mathrm{C}$ or as high as $35^{\circ} \mathrm{C}$ have been recorded.

Due to the climatic and geomorphological characteristics, the vegetational cover is marked by the presence of saltmarshes and mangroves on the margins of the mixohaline bodies of water and by dune vegetation of Atlantic forests on the higher areas.

\section{Materials and Methods}

Fourteen cores were collected with the aid of a Rossfelder VT-1 vibracorer, along the main channel of the lagoonal system (Fig. 2).
Prior to the opening, the cores were analyzed for magnetic susceptibility in a Bartington MS-2C system with a resolution of $1.10^{-6}$ S.I. The measurements were made every centimeter.

Based on the magnetic susceptibility profiles, one core, which showed the best possibility of representing both phases prior to and after the opening of the Valo Grande, was chosen. This core (CAN-05), located at the coordinates $24^{\circ} 45.245^{\prime} \mathrm{S}$ $47^{\circ} 37.370$ ' $\mathrm{W}$ and with $200 \mathrm{~cm}$ in length, was opened, described, and sampled continuously at every $2 \mathrm{~cm}$. In order to avoid along-core contamination, only the internal area of the recovered sediment was used for analysis. Samples for physical and chemical analyses were immediately frozen for freeze-drying at a later date, and samples for microfaunal analyses were oven-dried at $40^{\circ} \mathrm{C}$.

Sedimentation rates were determined via gamma spectrometry, by means of the ${ }^{210} \mathrm{~Pb}$ photopeak of $47 \mathrm{keV}$ using a low background Ge detector, EG\&G Ortec, model GMX 25190P, as described in Figueira et al. (2007)

Grain size analyses were performed on decarbonated samples using a Malvern Mastersizer 2000 Laser Analyser. Total organic matter content was determined via weight difference prior and after muffling the sample at $550^{\circ} \mathrm{C}$ for two hours (BYERS et al., 1978).

Calcium carbonate content was determined by weight differences prior to and after the acidification of each sample with $1 \mathrm{~N} \mathrm{HCl}$.

Elemental analyses $(\mathrm{Al}, \mathrm{Sc}, \mathrm{Cu}, \mathrm{Pb}$, and $\mathrm{Zn})$ were performed using the ICP-OES technique with a Varian model Vista MPX. The analysis followed the procedures described in Method 3050b of the SW-846 series (USEPA, 2008). Approximately $1 \mathrm{~g}$ of dry sediment was digested with $10 \mathrm{~mL}$ of $1: 1 \mathrm{HNO}_{3}$ at $95^{\circ} \mathrm{C}$ for 15 minutes. After cooling, another $5 \mathrm{~mL}$ of concentrated $\mathrm{HNO}_{3}$ was added, and the solution was heated for 30 minutes. This second procedure was repeated until the digestion of the sample was complete. Two milliliters of water and $3 \mathrm{~mL}$ of $30 \%$ $\mathrm{H}_{2} \mathrm{O}_{2}$ were added as the sample was heated until the elimination of the organic matter was complete. After this step, $10 \mathrm{~mL}$ of concentrated $\mathrm{HCl}$ was added, and the solution was heated for 15 minutes. Finally, the solution was filtered through a Whatman 41 filter, and $10 \mathrm{~mL}$ of concentrated $\mathrm{HCl}$ was added to the digestate. Finally, the solution was filtered again in a Whatman 41 filter, and the filtrate was collected in a $100 \mathrm{~mL}$ volumetric flask. The volume was completed, and the solution was analyzed in a Varian ICP-OES, model Vista MPX. The measurement precision for all elements was at least 5\%. Method accuracy was obtained by analyzing certified standards. 


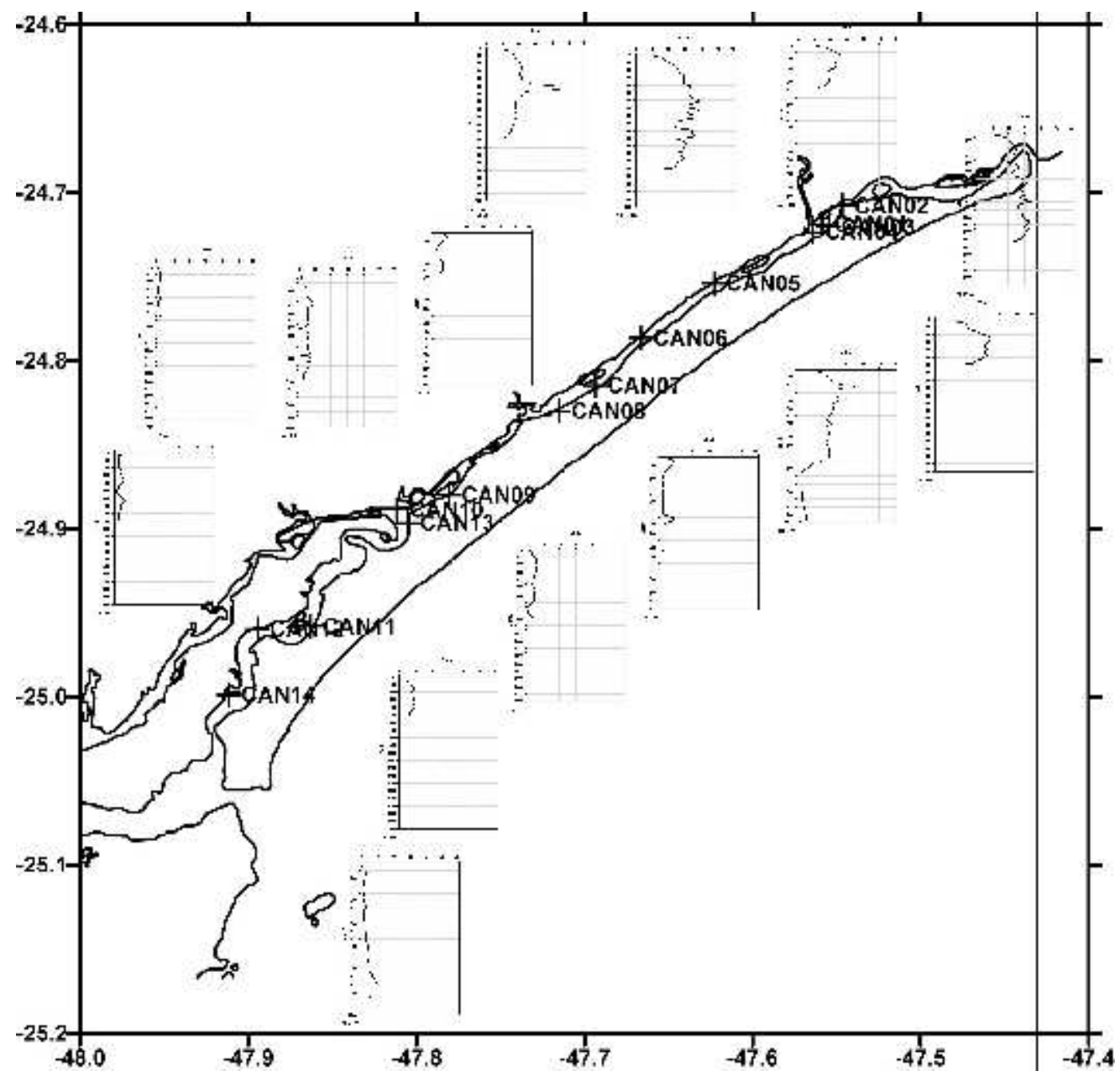

Fig. 2. Location of the fourteen cores analyzed for magnetic susceptibility, as well as core CAN05.

In order to assess the degree of sediment contamination, the enrichment factors (EF) were calculated with respect to the normalized value of Sc using the formula:

$\mathrm{EF}=\left(\mathrm{X}_{\mathrm{i}} / \mathrm{Sc}_{\mathrm{i}}\right) /\left(\mathrm{X}_{0} / \mathrm{Sc}_{0}\right)$,

where:

$X_{i}$ is the metal concentration value in the sample;

$X_{O}$ is the metal background value;

$S c_{i}$ is the Sc concentration in the sample; and

$S c_{0}$ is the Sc background value.

Elemental values were normalized by levels of scandium, which is used as a conservative element for normalization. The background values corresponded to the average element concentrations of the five bottommost samples, which were assumed to correspond to sediments deposited prior to the complete opening of the Valo Grande, as determined by the ${ }^{210} \mathrm{~Pb}$ chronology. The five-category pollution index (ANDREWS; SUTHERLAND, 2004) was used for the pollution assessment: $\mathrm{EF}<2$, minimal pollution; EF 2-5, moderate pollution; EF 5-20, significant pollution; EF 20-40, high pollution; and $E F>40$, extreme pollution.

In order to study the benthic foraminiferal fauna, a volume of about $20 \mathrm{~cm}^{3}$ was extracted from each layer in intervals of 10 centimeters. Samples were carefully washed through the $0.062 \mathrm{~mm}$ sieve, washed with water to remove silt and clay fractions, and then dried at $40^{\circ} \mathrm{C}$. The remaining portion in the sieve was then subjected to flotation with carbon trichloroethylene to concentrate the Foraminifera as described by Murray (1979). The floated material was transferred to filter paper and air-dried. All specimens in each sample were picked up under a stereoscopic binocular microscope using reflected light and 
identified following the generic classification of Loeblich and Tappan (1988). The heavy residue was examined for possible unfloated shells.

The data were analyzed using univariate methods. Diversity $\left(H^{\prime}\right)$ was calculated on a natural logarithmic basis (ln $\mathrm{x}$ ) by the Shannon-Wiener index (SHANNON; WEAVER, 1963); the evenness ( $J^{\prime}$ ) was calculated according to Pielou (1975); and species richness $(S)$ was determined as the total number of species. A Pearson Correlation Analysis, considering the statistical significance $(\alpha \leq 0.05)$ has been performed between the biotic and the sedimentological and geochemical parameters.

\section{RESUlts}

Age-Depth Model

The average sedimentation rate of the core, obtained by ${ }^{210} \mathrm{~Pb}$ dating, is about $0.887 \pm 0.166 \mathrm{~cm} \cdot \mathrm{y}^{-1}$. This represents a time interval of $177 \pm 33$ years for the sequence sampled, confirming that its base represents a period prior to the opening of the Valo Grande. Assuming that this calculation is valid, we may expect that sedimentological, geochemical and microfaunistic changes occur between the depths of 120 and 160 centimeters.

\section{Sedimentological Changes}

The sedimentological variability is shown in Figure 3. There was a marked break in the sedimentation at $130 \mathrm{~cm}$. At the top of this limit, we observed a marked decrease in grain size, concurrent with an increase in organic matter, water content, magnetic susceptibility and calcium carbonate.

A second limit was observed at $50 \mathrm{~cm}$, but it is noticeable only on the increase in magnetic susceptibility and the slight decrease in calcium carbonate.

These two limits mark three different depositional zones. The basal zone is marked by magnetic susceptibility values lower than $10.10^{-5}$ S.I., a water content of less than $40 \%$, a calcium carbonate content and an organic matter content of less than 5\%, and a sandy sedimentation, with mud (clay + silt) of less than $20 \%$.

The intermediate zone was characterized by magnetic susceptibility values between 10 and $25.10^{-5}$ S.I., a water content higher than $50 \%$, calcium carbonate values between 8 and $12 \%$, an organic matter content higher than $10 \%$, and a muddy sedimentation, marked by a clay + silt content of more than $70 \%$.

Finally, the topmost zone was characterized by the presence of the highest values of magnetic susceptibility. The decrease of the susceptibility values at the shallower samples was probably caused by a border effect. We also observed a decrease of calcium carbonate to values between 6 and 10\%; changes in organic matter and grain-size, if present, were too discrete to be described.

\section{Heavy Metals}

Table 1 presents the minimum, maximum, mean, standard deviation and median of the heavy metals (in mg. $\mathrm{kg}^{-1}$ ) analyzed in this study.

Box-plots of heavy metals variations, considering the time intervals prior and after the opening of the Valo Grande and prior and after the activities of the Plumbum mining activities are shown in Figure 4.

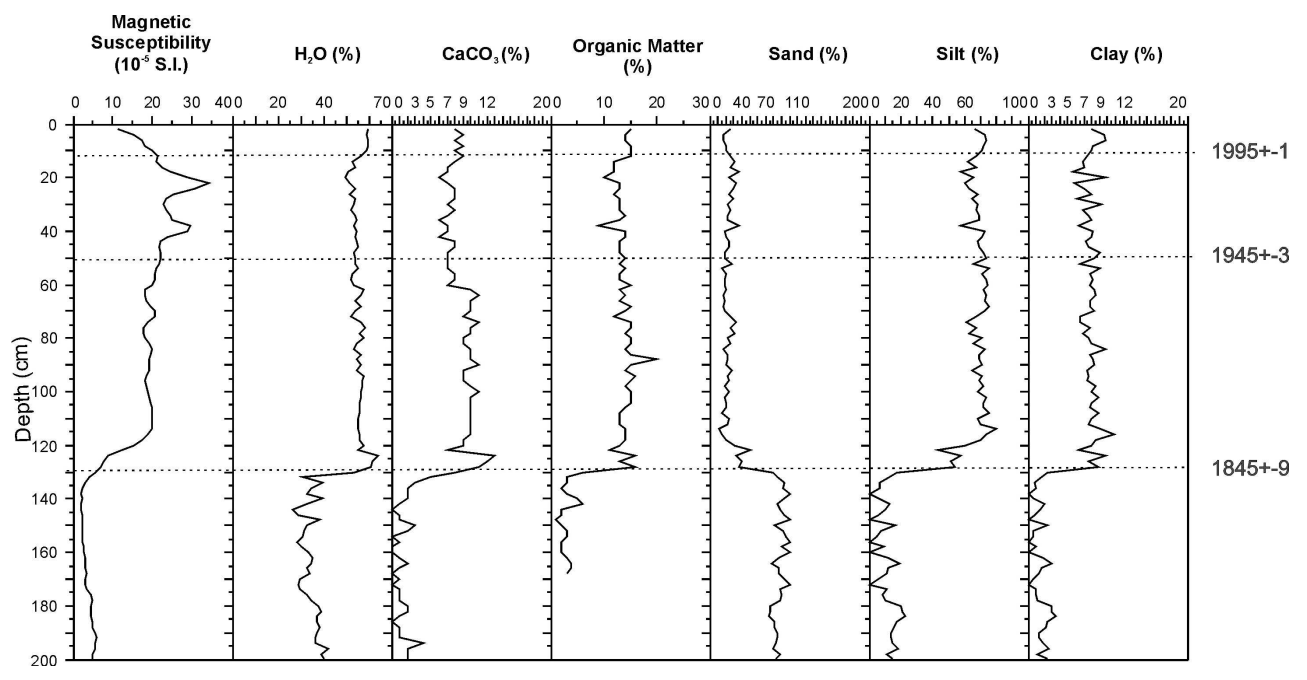

Fig. 3. Variations in the sedimentary parameters of core CAN05. 
Table 1. Minimum, maximum, mean, standard deviation and median values of the heavy metals $(\mathrm{Cu}, \mathrm{PB}, \mathrm{Zn}$, and Cr) analyzed in this study.

\begin{tabular}{|c|c|c|c|c|c|}
\hline & & $\mathrm{Cu}$ & $\mathrm{Pb}$ & $\mathrm{Zn}$ & $\mathrm{Cr}$ \\
\hline Total & Minimum & 1,4 & 2,2 & 8,6 & 4,9 \\
\hline \multirow[t]{4}{*}{$\mathrm{n}=84$} & Maximum & 32,1 & 68,2 & 92,1 & 52,2 \\
\hline & Mean & 20,5 & 21,7 & 65,1 & 35,0 \\
\hline & Std Dev & 10,1 & 13,3 & 27,3 & 14,2 \\
\hline & Median & 25,0 & 20,1 & 77,5 & 40,6 \\
\hline \multirow{5}{*}{$\begin{array}{l}\text { Pre-Valo Grande Opening } \\
\mathrm{n}=11\end{array}$} & Minimum & 1,4 & 2,2 & 8,8 & 4,9 \\
\hline & Maximum & 5,6 & 7,9 & 30,8 & 19,6 \\
\hline & Mean & 3,1 & 4,5 & 17,9 & 11,0 \\
\hline & Std Dev & 1,3 & 1,9 & 7,0 & 4,5 \\
\hline & Median & 2,6 & 4,0 & 16,0 & 10,3 \\
\hline \multicolumn{6}{|c|}{ Post Valo Grande Opening / Pre Plumbum } \\
\hline Operations & Minimum & 2,0 & 2,2 & 8,6 & 5,2 \\
\hline \multirow[t]{4}{*}{$\mathrm{n}=44$} & Maximum & 30,2 & 30,7 & 92,1 & 52,2 \\
\hline & Mean & 23,4 & 19,1 & 77,0 & 42,2 \\
\hline & Std Dev & 7,1 & 5,1 & 19,2 & 10,1 \\
\hline & Median & 25,7 & 19,6 & 84,6 & 44,1 \\
\hline \multirow{5}{*}{$\begin{array}{l}\text { Plumbum Operations } \\
\mathrm{n}=24\end{array}$} & Minimum & 22,6 & 21,0 & 55,0 & 27,0 \\
\hline & Maximum & 30,1 & 68,2 & 90,5 & 47,7 \\
\hline & Mean & 25,4 & 34,5 & 75,3 & 38,3 \\
\hline & Std Dev & 2,0 & 11,8 & 10,7 & 5,8 \\
\hline & Median & 25,0 & 35,3 & 79,3 & 39,7 \\
\hline \multirow{5}{*}{$\begin{array}{l}\text { Post Plumbum Operations } \\
\mathrm{n}=5\end{array}$} & Minimum & 30,3 & 40,9 & 68,6 & 36,9 \\
\hline & Maximum & 32,1 & 43,1 & 75,6 & 40,0 \\
\hline & Mean & 31,3 & 41,8 & 72,7 & 38,1 \\
\hline & Std Dev & 0,7 & 0,9 & 2,7 & 1,3 \\
\hline & Median & 31,4 & 41,7 & 72,5 & 38,1 \\
\hline
\end{tabular}
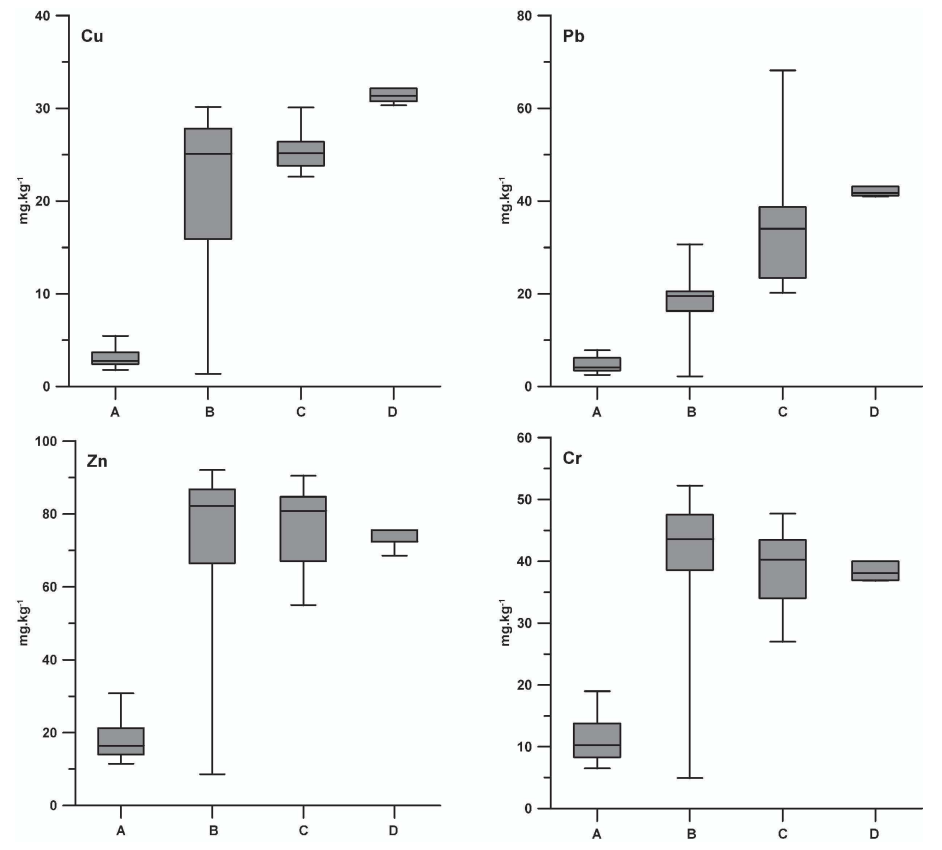

Fig. 4. Boxplots, indicating minimum, maximum, median, lower and upper quartiles of the metal variations along the cores. A) Pre-Valo Grande opening. B) Post Valo Grande opening / Pre Plumbum operations. C) During Plumbum mining operation. D) Post Plumbum mining operation. 
Maximum values of $\mathrm{Cu}$ and $\mathrm{Pb}$ were about $30 \mathrm{x}$ higher than minimum values. For $\mathrm{Zn}$ and $\mathrm{Cr}$, this difference was approximately 10x. All of the metals showed a general trend of increasing concentrations towards the shallower strata, but the highest values were not located in the topmost samples (Fig. 5a).
The heavy metal $(\mathrm{Cu}, \mathrm{Pb}, \mathrm{Zn}$, and $\mathrm{Cr})$ contents of the sediments were better described in terms of their Enrichment Factors (EFs; Fig. 5b). The EFs of both $\mathrm{Zn}$ and $\mathrm{Cr}$ presented a similar trend, with an increase in levels shallower than $130 \mathrm{~cm}$ and a decrease after $30 \mathrm{~cm}$. Nevertheless, these elements presented EF values close to the background levels.
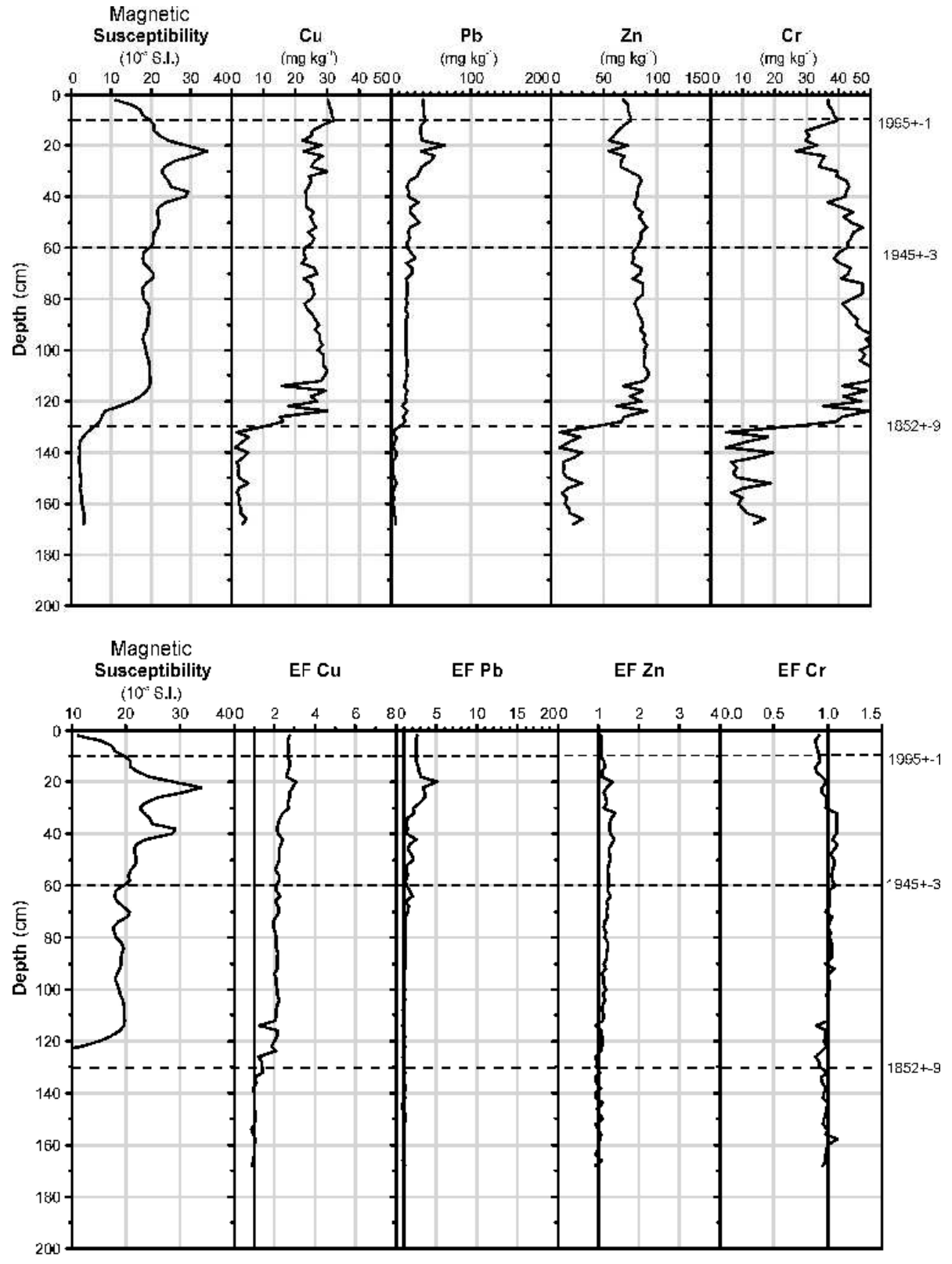

Fig. 5a. Variations in $\mathrm{Cu}, \mathrm{Pb}, \mathrm{Zn}$ and $\mathrm{Cr}$ contents along core CAN05. b. Variations in the Enrichment Factors (EFs) of $\mathrm{Cu}, \mathrm{Pb}, \mathrm{Zn}$ and $\mathrm{Cr}$ along core CAN05. 
The trend of the $\mathrm{EF}$ of $\mathrm{Cu}$ showed a continuous increase of the values towards the top of the core, with the highest value observed at $20 \mathrm{~cm}$. A similar behavior was observed in the EF values of $\mathrm{Pb}$, with an $\mathrm{EF}$ value higher than 5 at $20 \mathrm{~cm}$. A distinctive feature between these elements is the fact that the $\mathrm{EF}$ of $\mathrm{Cu}$ increased from $130 \mathrm{~cm}$ towards the top, and, for $\mathrm{Pb}$, the EF increased after $70 \mathrm{~cm}$.

\section{Microfaunal Content}

In total, 893 individual tests were found (32 species of Foraminifera and 4 of Thecamoebian; Table 2) on 29 samples analyzed. Based on the distribution patterns of foraminifera and the abundance of thecamoebians, the three different zones that have been previously described for sedimentology may also be distinguished in this core (Fig.s 6 and 7).

Table 2. Abundance of foraminifers and thecamoebians along core CAN05.

\begin{tabular}{|c|c|c|c|c|c|c|c|c|c|c|c|c|c|}
\hline Species /Level (cm) & 3 & $48-50$ & 1110-112 & $128-130$ & 134-136 & 138-140 & 142-144 & T146-148 & $148-150$ & 150-152 & 156-158 & $160-162$ & T170-172 \\
\hline \begin{tabular}{|l} 
Ammonia tepida \\
\end{tabular} & & & & 1 & 13 & 32 & 283 & 49 & \begin{tabular}{l|l}
9 & 81
\end{tabular} & 58 & 3 & & \\
\hline Bolivina $s p$. & & & & & 1 & 1 & & & & & 1 & & \\
\hline Brizalina striatula & & & & & & & 1 & & & 1 & & & \\
\hline Buliminella elegantissima & & & & & 1 & 2 & 2 & & & 1 & & & \\
\hline Cassidulina sp. & & & & & & & & & & & 1 & & \\
\hline Discorbis sp. & 1 & & & & & & 1 & & & & & & \\
\hline Elphidium spp. & & & & & 39 & 28 & 39 & 15 & 20 & 26 & & & \\
\hline Fissurina sp. & & & & & & 1 & & & & $\frac{1}{1}$ & & & \\
\hline Pseudononion aflanticum & & & & & & & & 1 & & & & & \\
\hline Quinqueloculina sp. & & & & & & & & & & & & 3 & \\
\hline Ammobaculites exiguus & 1 & & & 2 & 6 & 1 & & & & 2 & & 2 & \\
\hline Ammotium salsum & & & & & 17 & & 7 & 3 & 1 & 5 & 5 & 5 & \\
\hline Ammoastuta salsa & & & & & 2 & 1 & & & & & & & \\
\hline Arenoparrella mexicana & & & & & & & & 3 & & & 1 & & \\
\hline Clavulina sp. & & & & & & & 1 & & & & & & \\
\hline Glomospira sp. & & & & & & & & & & & & & \\
\hline Haplophragmoides sp. & & & & 1 & & & & & & & & & \\
\hline Miliammina fusca & 10 & 18 & 1 & & & & & & & & & & \\
\hline Trochammina sp. & $\frac{\pi}{2}$ & & & & 1 & & 3 & & 1 & & & 1 & \\
\hline Trochammina ochracea & & & & & & & 1 & & & & & 1 & \\
\hline 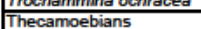 & 4 & 1 & & & & 2 & & & & & & & \\
\hline Aglutinants not identified & & & & & & & & & & & & & \\
\hline Total Density & 18 & 22 & & 4 & 201 & 68 & 138 & 71 & 103 & 94 & 10 & $\overline{12}$ & \\
\hline
\end{tabular}

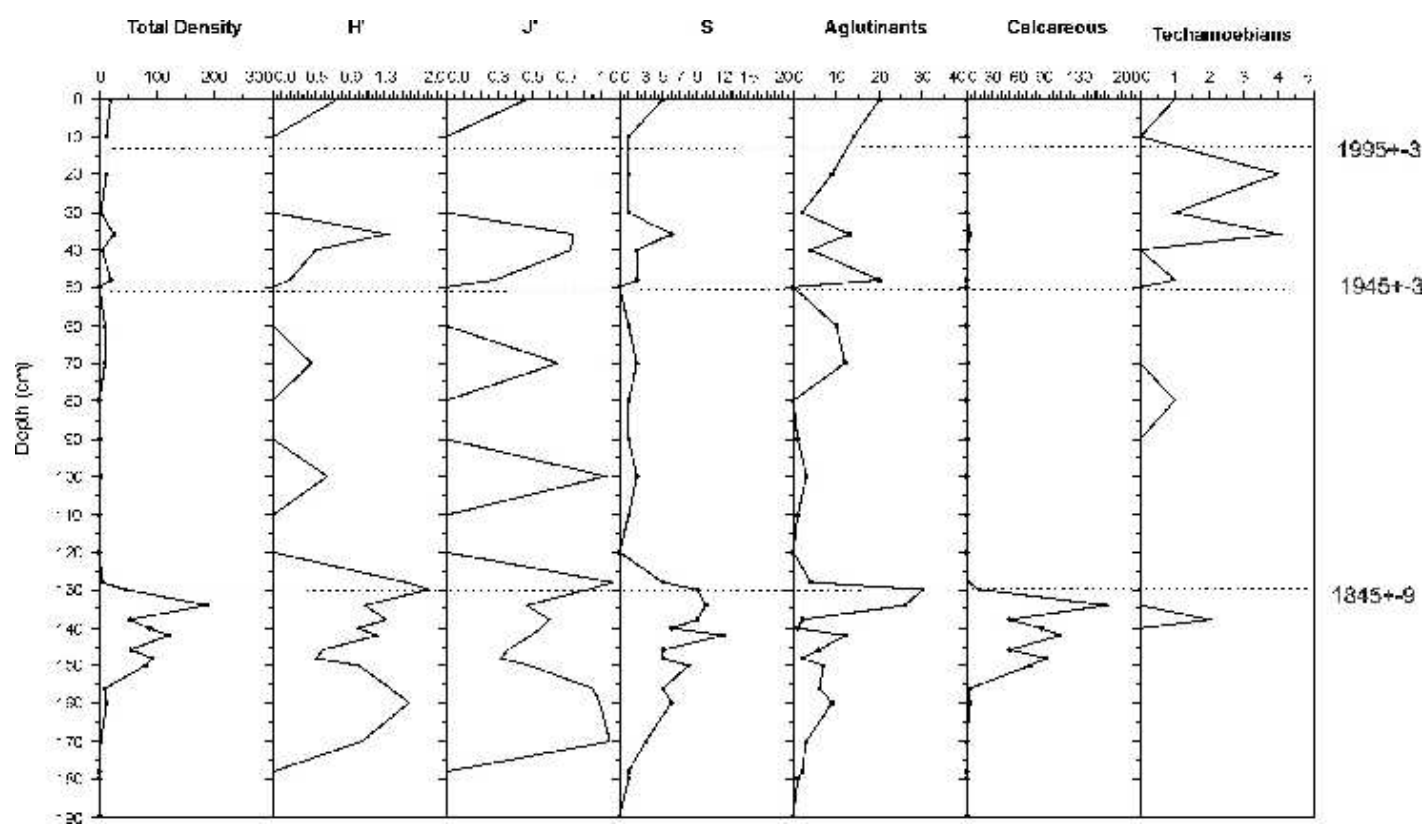

Fig. 6. Variations in the populational parameters of foraminifers and thecamoebians along core CAN05. 


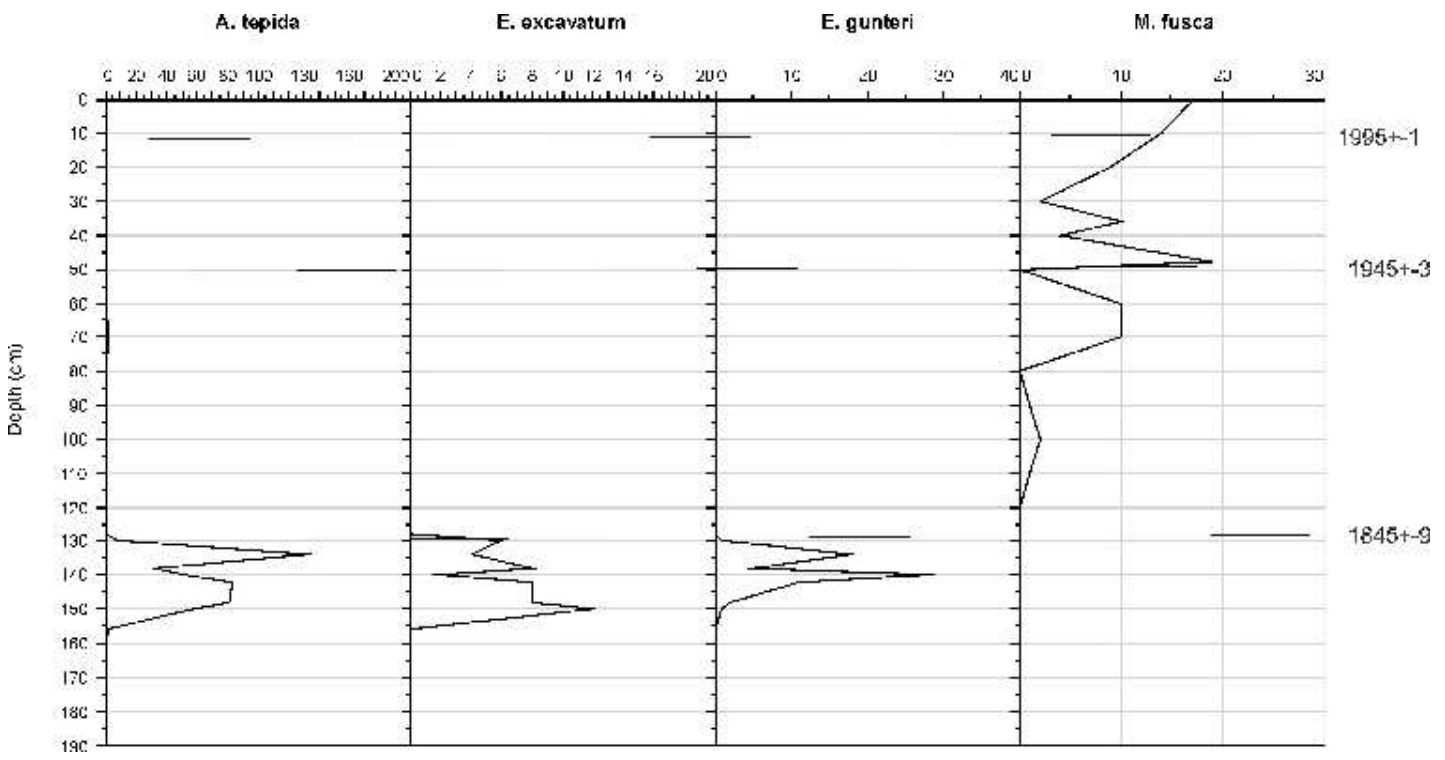

Fig. 7. Variations in the dominant species of foraminifers along core CAN05.

The highest values of total density, diversity and richness were observed in the basal zone, from 200 to $130 \mathrm{~cm}$. This zone was also marked by the presence of mixohaline calcareous foraminifers, dominated by the generalist species Ammonia tepida, Elphidium excavatum and Elphidium gunteri, which can survive in unstable environments (WALTON; SLOAN, 1990). This foraminiferal association disappears at depths shallower than $130 \mathrm{~cm}$.

The intermediate zone was characterized by a drastic change in the microfaunal content. In this zone, the presence of azoic levels is noticeable. Few agglutinant foraminifers and thecamoebians were found, and their total density and richness reached the lowest values in the core.

The topmost zone was marked by a slight increase in total density and richness, reflecting the increase in agglutinant and thecamoebian species.

When analyzing the foraminiferal content (Fig. 7), we clearly observe the environmental modifications that occurred and were recorded in the core. The basal zone was marked by the presence of A. tepida, E. excavatum and $E$. gunteri; these species virtually disappeared from the core after a depth of $130 \mathrm{~cm}$ and were substituted by the agglutinant species Miliammina fusca, which increased in abundance after a depth of $50 \mathrm{~cm}$.

\section{DisCUSSION}

The first aspect that must be considered in our data is the age-depth model, which is the most important factor for the interpretation of historical changes in the study area. In fact, the value of $0.887 \pm 0.166 \mathrm{~cm} \cdot \mathrm{yr}^{-1}$ corresponds to an average estimate for the muddy level of core (topmost 130 $\mathrm{cm})$. Nevertheless, we may not expect a constant sedimentation rate for the whole core. In fact, this assumption does not discredit the interpretation of our results, and it allowed us to recognize the influence of the opening of the Valo Grande, completed in 1852.

The integrated analysis of the data indicates the occurrence of conspicuous changes in the sedimentary processes of the Cananéia-Iguape system, which were related to the opening of the Valo Grande with the consequent input of freshwater, muddy sediments and heavy metals to the environment.

As a consequence of this input, one of the most drastic changes is related to modifications of the biota, with the extinction of the calcareous foraminifers and the occurrence of azoic levels in the sediment. The new assemblage that succeeded the Ammonia and Elphidium assemblage was observed at the base of the core. This assemblage is defined by organisms adapted to freshwater and high organic matter content, especially thecamoebians and the foraminifer species Miliammina fusca. A similar association was described by Dias-Brito and Oliveira (1999) in Itanhaém (SE Brazilian coast), located less than $100 \mathrm{~km}$ northward of our study area, and it was thought to be characteristic of oligohaline environments with salinities between 0.5 and 5.0. 
These environmental changes were confirmed by the positive and significant correlation $(\alpha \leq 0.05)$ between the dominant calcareous species (see Table 3 ) and the sand content, as well as by the significant correlation between $M$. fusca and organic matter, silt and clay contents.

A comparison of our data with anthropogenically affected sediments in the Bilbao estuary, Spain (CEARRETA et al., 2002), the SW Iberian shelf (CORREDEIRA et al., 2008), and Santos bay and estuary, SE Brazil (TESSLER et al., 2006) revealed that the sediments from the core analyzed here are significantly poorer in heavy metals than those from the Iberian sediments. On the other hand, after the opening of the Valo Grande, levels of $\mathrm{Pb}, \mathrm{Cu}$, $\mathrm{Zn}$ and $\mathrm{Cr}$ were of the same order of magnitude as those from the highly polluted Santos estuary (Table $1)$.

Another aspect to be considered is the impact caused by the beginning of the mining activities of the Plumbum S/A, specifically in terms of the input of $\mathrm{Pb}$ into the coastal system.

The Enrichment Factor (EF) is considered to be a reliable estimate for the input of metals in a given environment and can be especially useful for analyzing anthropogenic influences (CEARRETA et al., 2002). In this sense, the variations in the EFs of the core analyzed here could be efficiently used for the analysis of the historical changes that occurred in the Cananéia-Iguape system.

When we compare the variations in the EF with the age-model, the effect of the opening of the Valo Grande on the input of heavy metals into the coastal system can be clearly observed. The immediate increase in the input of $\mathrm{Cu}$ just after the opening of the Valo Grande is evident. On the other hand, the increase in the $\mathrm{EFs}$ of $\mathrm{Pb}$ is much more evident after the beginning of mining industry operations in 1945. The EF values observed for the interval that corresponded with the activities of Plumbum S/A reached levels of moderate to significant pollution in the site where the core was collected (approximately $7.5 \mathrm{~km}$ west from the mouth of the Valo Grande).

Another important aspect of the sediments analyzed is the fact that the input of heavy metals, especially $\mathrm{Pb}$, did not end after the operations of Plumbum S/A ceased in 1995, as recorded in the topmost levels of the core. It is possible that the input of metals to the Ribeira river sediments still occur due to weathering of the slag heaps that are still present in the drainage basin.

\section{Conclusions}

Using a multi-proxy approach, it was possible to recognize the occurrence of conspicuous environmental changes in the Cananéia-Iguape system in the last two centuries.

These environmental changes were essentially related to the opening of the Valo Grande artificial channel and were implied in significant modifications in salinity, in changes of the depositional patterns of sediments and foraminiferal assemblages (including periods of defaunation), and, more drastically, in the input of heavy metals. The concentrations $\mathrm{Pb}$ in the core analyzed here were up to two times higher than the values measured in contaminated sediments from the Santos estuary, the most industrialized coastal zone in Brazil. The levels of $\mathrm{Cu}$ and $\mathrm{Cr}$ were of the same order of magnitude.

The Enrichment Factors determined along the sedimentary column revealed that during the activities of the Plumbum S/A mining industry, the environment presented levels of $\mathrm{Pb}$ equivalent to moderate to significant pollution. Even after the end of the activities of the mining industry, the input of heavy metals, especially $\mathrm{Cu}$ and $\mathrm{Pb}$, persists, indicating a continued input of heavy metals from the disposal pills of the upper course of the Ribeira River.

Table 3. Pearson correlation analysis between the biotic and the sedimentological and geochemical parameters. Statistically significant values $(\alpha \leq 0.05)$ are highlighted.

\begin{tabular}{|c|c|c|c|c|c|c|c|c|c|c|c|c|}
\hline & Magnetic Suscep. & $\mathrm{H}_{2} \mathrm{O}$ & $\mathrm{CaCO}_{3}$ & O.M. & Sand & silt & Clay & Al & Cu & $\mathbf{P b}$ & $\mathrm{Zn}$ & $\mathrm{Cr}$ \\
\hline A. tepida & -0.508 & -0.436 & -0.428 & -0.466 & 0.525 & -0.525 & -0.515 & -0.680 & 0.387 & -0.242 & 0.385 & 0.440 \\
\hline E. excavatum & $=0.532$ & -0.462 & -0.382 & $=0.499$ & 0.532 & $=0.534$ & $=0.512$ & $=0.848$ & 0.476 & -0.305 & 0.436 & 0.490 \\
\hline E. gunteri & -0.401 & -0.303 & -0.336 & -0.304 & $\overline{0.421}$ & -0.420 & -0.422 & -0.640 & 0.208 & -0.266 & 0.206 & 0.283 \\
\hline M. fusca & 0.532 & 0.477 & 0.342 & 0.509 & $=0.566$ & 0.567 & 0.547 & 0.310 & -0.265 & 0.573 & -0.206 & -0.457 \\
\hline Total Density & -0.539 & -0.494 & -0.455 & -0.488 & 0.564 & -0.564 & -0.552 & $\underline{-0.717}$ & 0.394 & -0.213 & 0.393 & 0.411 \\
\hline $\mathbf{H}^{\mathbf{2}}$ & $=0.590$ & -0.390 & -0.350 & $=0.510$ & 0.600 & $=0.610$ & $=0.520$ & -0.520 & 0.450 & -0.160 & 0.390 & 0.300 \\
\hline $\mathbf{J}^{\prime}$ & -0.352 & -0.245 & -0.178 & -0.235 & 0.361 & -0.368 & -0.350 & -0.431 & 0.179 & -0.018 & 0.136 & 0.077 \\
\hline $\mathbf{s}$ & $=0.657$ & $=0.53 .37$ & -0.487 & -0.522 & 0.669 & 0.671 & $=0.646$ & $=0.811$ & 0.400 & -0.305 & 0.363 & 0.390 \\
\hline Thecamoebians & 0.416 & 0.149 & 0.051 & 0.158 & -0.254 & 0.250 & 0.289 & -0.034 & -0.358 & -0.060 & -0.339 & -0.305 \\
\hline Agglutinant & -0.049 & 0.106 & 0.038 & -0.005 & 0.041 & -0.041 & -0.039 & -0.212 & 0.335 & 0.197 & 0.320 & 0.125 \\
\hline Calcareous & -0.577 & -0.549 & -0.490 & -0.522 & 0.599 & -0.599 & -0.587 & -0.732 & 0.375 & -0.270 & 0.377 & 0.439 \\
\hline
\end{tabular}




\section{ACKNOWLEDGMENTS}

The authors are indebted to the crew of the Research Boat Albacora, to $\mathrm{Mr}$ Clodoaldo Vieira Tolentino and Mr Edilson de Oliveira Faria, for the help during sampling. Thanks are also due to $\mathrm{Mr}$ Alexandre Barbosa Salaroli and Mr Tito Conti, for the help in geochemical analyses.

Thanks are due to the reviewers of Brazilian Journal of Oceanography for the suggestions to the manuscript.

Financial Support was provided by the Fundação de Amparo à Pesquisa do Estado de São Paulo, Grant 2006/04344-2.

\section{REFERENCES}

ALVE, E. Benthic foraminífera in sediment cores reflecting heavy metal pollution in SØrfjord, western Norway. J. foram. Res., v. 21, p. 1-19, 1991.

ALVE, E. Benthic foraminiferal responses to estuarine pollution: a review. J. foram. Res., v. 25, p. 190-203, 1995.

ANDREWS, S.; SUTHERLAND, R. A. $\mathrm{Cu}, \mathrm{Pb}$ and $\mathrm{Zn}$ contamination in Nuuanu watershed, Oahu, Hawaii. Sci. total Environment, v. 324, p. 173-182, 2004.

BESNARD, W. Considerações gerais em torno da Região Lagunar de Cananéia-Iguape. Bolm Inst.. paul. Oceanogr., v. 1, p. 9-26, 1950.

BIRCH, G.; TAYLOR. S. Source of heavy metals in sediments of the Port Jackson estuary, Australia. Sci. total Environment, v. 227, p. 123-138, 1999.

BYERS, S.; MILLS, E.; STEWART, P. Comparison of methods of determining organic carbon in marine sediments, with suggestions for a standard method. Hydrobiologia, v. 58, p. 43-47, 1978.

CEARRETA, A.; IRABIEN, M. J.; LEORRI, E.; YUSTA, I.; CROUDACE, I. W.; CUNDY, A. B. Recent anthropogenic impacts on the Bilbao Estuary, Northern Spain: Geochemical and Microfaunal Evidence. Estuar. coast. Shelf Sci., v. 50, p. 571-592, 2000.

CEARRETA, A.; IRABIEN, M. J.; LEORRI, E.; YUSTA, I.; QUINTANULLA, A.; ZABALETA, A. Environmental transformation of the Bilbao estuary, N. Spain: microfaunal and geochemical proxies in the recent sedimentary record. Mar. Pollut. Bull., v. 44, p. 487$503,2002$.

CHAN, L. S.; NG, S. L.; DAVIS, A. M., YIM, W.W.S.; YEUNG, C. H. Magnetic properties and heavy-metal contents of contaminated seabed sediments of Penny's Bay, Hong Kong. Mar. Pollut. Bull., v. 42, p. 569-583, 2001.

CORREDEIRA, C.; ARAUJO, M. F.; JOUANNEAU, J. M. Copper, zinc and lead impact in SW Iberian shelf sediments: An assessment of recent historical changes in Guadiana river basin. Geochem. J., v. 42, p. 319-329, 2008.

CUNDY, A. B.; CROUDACE, I. W.; CEARRETA, A.; IRABIEN, M. J. Reconstructing historical trends in metal input in heavily-disturbed, contaminated estuaries: studies from Bilbao, Southampton Water and Sicily. 1. Appl. Geochem.., v. 18, p. 311-325, 2003.
DASSENAKIS, M.; A. DEGAITA; SCOULLOS, M. Trace metals in sediments of a Mediterranean estuary affected by human activities (Achellos river estuary, Greece). Sci. total Environment, v. 168, p. 19-31, 1995.

DIAS-BRITO, D.; OLIVEIRA, D. Integrating Foraminifera, Thecamoebians and plant distribution data to understand the environmental succession in a hydrographic basin: an example from Itanhaém-SP, Southeastern coast of Brazil. In: Ecological and paleoenvironmental applications. Porto Seguro: Associação Brasileira de Estudos do Quaternário. CDROM:viiabequa_tmo010.pdf, 1999.

DONDERS, T. H.; GORISSEN, P.M.; SANGIORGI, F.; CREMER, H.; WAGNER-CREMER, F. Three-hundredyear hydrological changes in a subtropical estuary, Rookery Bay (Florida): Human impact versus natural variability. Geochem., Geophys. , Geosystems, v. 9, Q07V06, doi:10.1029/2008GC001980, 2008.

ELBERLING, B.; KNUDSEN, K.L.; KRISTENSEN, P.H.; ASMUND, G. Applying foraminiferal stratigraphy as a biomarker for heavy metal contamination and mining impact in a fiord in West Greenland. Mar. environ. Res., v. 55, p. 235-256, 2003.

FIGUEIRA, R.C.L.; TESSLER, M. G.; MAHIQUES, M. M.; FUKUMOTO, M. M. Is there a technique for the determination of sedimentation rates based on calcium carbonate content? A comparative study on the Southeastern Brazilian shelf. Soils Found., v. 47, p. 649-656, 2007.

FOX, W. M.; JOHSON, M. S.; JONES, S. R.; LEAH, R. T.; COPPLESTONE, D. The use of sediment cores from stable and developing salt marshes to reconstruct historical contamination profiles in the Mersey Estuary, UK. Mar. environ. Res., v. 47, p. 311-29, 1999.

GEOBRÁS. Complexo Valo Grande, Mar Pequeno, Rio Ribeira de Iguape. Relatório para o serviço do Vale do Ribeira - São Paulo: DAEE, v. 1, 1966. 448 p.

HORNBERGER, M. I.; LUOMA, S. N.; VAN GEEN, A.; FULLER, C.; ANIMA, R. Historical trends of metals in the sediments of San Francisco Bay, California. Mar. Chem., v. 64, p. 39-55, 1999.

JONES, B.; TURKI, A. Distribution and speciation of heavy metals in surficial sediments from the Tees Estuary, north-east England. Mar. Pollut. Bull., v. 34, p. 768779, 1997.

LEORRI, E.; CEARRETA, A., IRABIEN, M. J., YUSTA, I. Geochemical and microfaunal proxies to assess environmental quality conditions during the recovery process of a heavily polluted estuary: The Bilbao estuary case (N. Spain). Sci. total Environment, v. 396, p. 1227, 2008.

LI, X.; O. W. H. WAI; LI, Y. S.; COLES B. J.; RAMSEY, H.; THORNTON, I. Heavy metal distribution in the sediment profiles of the Pearl River estuary, South China. Appl. Geochem., v. 15, p. 567-581, 2000.

LOEBLICH, A.R.; TAPPAN, H. Foraminiferal Genera and their classification. New York: Van Nostrand Reinhold, 1988, v. 1; 2. $270 p+212 p, 847$ pls.

MARTIN, L.; SUGUIO, K. Le Quaternaire Marin du littoral brésilien entre Cananéia et Barra de Guaratiba (RJ). In: INTERNATIONAL SYMPOSIUM ON COASTAL EVOLUTION IN THE QUATERNARY. São Paulo, 1978. Proceedings.... São Paulo, IGCP, p, 296-331, 1979. 
MURRAY, J. W. Recent benthic foraminiferids of the Celtic Sea. J. foram. Res., v. 9, p. 193-209, 1979.

PASTERNACK, G. B.; BROWN, K. J. Natural and anthropogenic geochemical signatures of floodplain and deltaic sedimentary strata, Sacramento-San Joaquin Delta, California, USA. Environ. Pollut, v. 141, p. 295 309, 2006.

PETRI, S.; SUGUIO, K. Some aspects on the Neocenozoic sedimentation in the Cananéia-Iguape lagoonal region, São Paulo, Brazil. Estudos Sedimentológicos, v. 1, 1971. p. 25-33

PETRI, S.; SUGUIO, K. Stratigraphy of the Iguape-Cananeia lagoonal region sedimentary deposits, São Paulo, Brazil Part II: Heavy minerals studies, micro-organisms inventories and strattigraphical interpretations. Bolm IG-USP, v. 4, p. 7-85, 1973

PIELOU, E. C. Ecological diversity. New York: John Wiley, 1975. $165 \mathrm{p}$

PLATER, A. J.; APPLEBY, P. G. Tidal sedimentation in the Tees estuary during the 20th century: radionuclide and magnetic evidence of pollution and sedimentary response. Estuar. coast. Shelf Sci., v. 60, p. 179-192, 2004.

PLATER, A. J.; RIDGWAY, J.; APPLEBY, P. G.; BERRY, A.; WRIGHT, M.R. Historical contaminant fluxes in the Tees estuary, UK: Geochemical, magnetic and radionuclide evidence. Mar. Pollut. Bull., v. 37, p. 343360, 1998.

RUIZ-FERNANDEZ, A. C.; HILLAIRE-MARCEL, C.; PAEZ-OSUNA, F.; GHALEB, B.; CABALLERO, M. $\mathrm{Pb}-210$ chronology and trace metal geochemistry at Los Tuxtlas, Mexico, as evidenced by a sedimentary record from the Lago Verde crater lake. Res Quat., v. 67, p.181-192, 2007.
SHANNON, C. E.; WEAVER, W.W. The mathematical theory of communication. Urbana: University of Illinois Press, 1963. $125 \mathrm{p}$.

SUGUIO, K.; L. MARTIN, L. Formações quaternárias marinhas do litoral paulista e sul-fluminense. In: INTERNATIONAL SYMPOSIUM ON COASTAL EVOLUTION IN THE QUATERNARY. Special Publication. São Paulo: Instituto de Geociências da Universidade de São Paulo - Sociedade Brasileira de Geologia, 1978. v. 1, p. 1-15.

TESSLER, M. G.; FIGUEIRA, R. C.; MAHIQUES, M. M.; FUKUMOTO, M. M.; CIAPINA, E. M. P. Sedimentation rates and contamination levels by heavy metals at the shallow sedimentary columns from Santos estuary and bay, SP, Brazil. J. coastal Res., v. SI39, p. 713-717, 2006

USEPA. Method 3050B. of Acid digestion sediments, sludges, and soils. United States

Environmental Protection Agency, 2008. <http://www.epa.gov/epawaste/hazard/testmethods/sw84 6/pdfs/3050b.pdf. > Last access on 06/03/2009.

WALTON, W. R; SLOAN, B. The genus Ammonia Brünnich 1972: its geographic distribution and morphological variability. J. foramin. Research, v. 20, p. 128-156, 1990.

(Manuscript received 25 March 2009; revised 17 June 2009; accepted 07 July 2009) 